\title{
CEA Family Gene
}

National Cancer Institute

\section{Source}

National Cancer Institute. CEA Family Gene. NCI Thesaurus. Code C25900.

Members of the CEA Family Gene encode the members of the CEA Family Protein, which consist of a single $\mathrm{N}$ domain, with structural similarity to the immunog lobulin variable domains, followed by a variable number of immunog lobulin constant-like A and/or B domains. (From OMIM and $\mathrm{NCl}$ ) 